\author{
A Dauphin MD CCFP FRCP,* \\ RN Gupta PHD, ${ }^{\dagger}$ \\ JEM Young MD FRCS, \\ WD Morton MD*
}

\section{Serum bupivacaine concentrations during continuous extrapleural infusion}

Purpose: To determine the rate of increase in serum bupivacaine concentration during continuous extrapleural infusion.

Methods: After thoracotomy for lobectomy under general anaesthesia, nine patients had an extrapleural catheter inserted, before chest closure, in a costovertebral gutter constructed surgically by lifting the parietal pleura. Bupivacaine $0.5 \%$ with epinephrine $1: 200.000$ was injected through the catheter as $0.3 \mathrm{ml} \cdot \mathrm{kg}$ ' bolus followed by $0.1 \mathrm{ml} \cdot \mathrm{kg}^{\prime} \cdot \mathrm{hr}^{-1}$ for five days. Serum bupivacaine (free and total), albumin, alpha-l acid glycoprotein concentrations were measured $15 \mathrm{~min}$ after injection and at $24 \mathrm{hr}$ intervals for five days. Bupivacaine concentrations were determined by column liquid chromatography using solid phase extraction. Serum alpha-I acid glycoprotein concentration was determined by nephelometry on QM 300 protein analyzer. Serum alburnin concentration was determined by bromocresol green dye binding procedure on Hitachi 717 Autoanalyzer.

Results: A continuous elevation in total serum bupivacaine was observed, with an average value of $0.75 \mu \mathrm{g} \cdot \mathrm{ml}$ ' on day 1 to $2.77 \mu \mathrm{g} \cdot \mathrm{ml}^{-1}$ on day $4(P<0.05)$. There was no increase in postoperative free serum bupivacaine concentration; average value of $177 \mathrm{pcg} \cdot \mathrm{ml}^{-1}$ on day 1 and $249 \mathrm{pcg} \cdot \mathrm{ml}^{-1}$ on day $4(P=0.92)$. Postoperative serum alpha- $I$ acid glycoprotein concentration showed a steady rise with an average value of $0.94 \mu \mathrm{g} \cdot \mathrm{ml}^{-1}$ on day $I$ and $1.47 \mu \mathrm{g} \cdot \mathrm{ml}$ ' on day $4(P<0.05)$. No change was observed in post-operative serum albumin with an average value of $31.4 \mathrm{~g}^{-1}$ on day 1 and $31.3 \mathrm{~g}^{-1}$ on day 4 .

Conclusion: Continuous extrapleural infusion of bupivacaine over five days after thoracotomy is associated with a steady increase in total serum bupivacaine concentration and no elevation in free serum bupivacaine concentration.

Objectif : Déterminer la vitesse de l'accumulation sérique de la bupivacaine pendant une perfusion extrapleurale continue.

Méthodes : Après une thoracotomie pour lobectomie sous anesthésie générale, on a inséré avant la fermeture de la plaie un cathéter extrapleural à neuf patients dans une gouttière costovertébrale créée chirurgicalement par soulèvement la plèvre pariétale. De la bupivacaïne $0.5 \%$ adrénalinée à $1: 200,000$ en bolus de $0.3 \mathrm{ml} / \mathrm{kg}^{\prime}$ suivi d'une perfusion de $0,1 \mathrm{ml} \cdot \mathrm{kg}^{-1} \cdot \mathrm{h}^{-1}$ était injectée par le cathéter pendant cinq jours. Les concentrations de bupivacaine sérique (libre et totale), de l'albumine, de lacide glycoprotéinique alpha-l étaient mesurées 15 min après l'injection et à des intervalles de $24 \mathrm{~h}$ pendant cinq jours. Les concentrations de bupivacaïne étaient mesurées par chromatographie sur colonne avec extraction en phase solide. L'acide glycoprotéinique alpha-l était déterminé par néphélométrie sur une analyseur de protéines QM 300. La concentration de l'albumine sérique était déterminée par le procédé de liaison au vert de bromocrésol sur Autoanalyzer Hitachi 717.

Résultats : Une élévation continue de la bupivacainne sérique totale a été observée avec une valeur moyenne de $0,75 \mu \mathrm{g} \cdot \mathrm{ml}^{-1}$ le premier jour $₫ 2,77 \mu \mathrm{g} \cdot \mathrm{ml}^{-1}$ le quatrième jour $(P<0,05)$. II riy pas eu d'élévation postopératoire de la concentration de bupivacainne sérique libre : valeur moyenne de $177 \mathrm{pcg} \cdot \mathrm{ml}^{-1}$ le premier jour et de $249 \mathrm{pcg} \cdot \mathrm{ml}$ ' le quatrième jour $(P=0,92)$. On a observé une concentration postopératoire sérique progressive de l'acide glycoprotéinique alpha-I avec une valeur moyenne de $0.94 \mu \mathrm{g} \cdot \mathrm{ml}^{-1}$ le premier jour et de $1.47 \mu \mathrm{g} \cdot \mathrm{ml}^{-1}$ le quatrième jour $(P<0,05)$. Aucun changement postopératoire de l'albumine sérique n'a été noté avec une valeur moyenne de $31.4 \mathrm{~g} \cdot \mathrm{L}^{-1}$ le premier jour et $31.3 \mathrm{~g} \cdot \mathrm{L}$ ' le quatrième jour.

Conclusion : Une perfusion continue extrapleurale de bupivacaine administrée pendant cinq jours est associée à une accumulation progressive de la bupivacaïne sérique totale sans élévation de la concentration de la bupivacaïne sénque libre.

From the Department of Anesthesia, ${ }^{*}$ Laboratory Medicine, ${ }^{\ddagger}$ and Surgery, ${ }^{\ddagger}$ St. Joseph’s Hospital, McMaster University, 50 Charlton Ave. E, Hamilton, Ontario L8N 4A6; Phone: 905-522-4941 ext. 3853.

Address correspondence to: Dr. Alezandre Dauphin.

Supported partially by a grant from Astra Pharma Inc. Accepted for publication December 22, 1996. 
B UPIVACAINE, an amide local anaesthetic, is one of the most commonly used local anaesthetics because of its long duration of action and vasoconstrictive effect. ${ }^{1}$ The manifestation of its toxicity includes central nervous system irritability causing convulsions and refractory cardiac arrhythmias leading to death. ${ }^{2}$ The threshold plasma concentration of bupivacaine at which central nervous system toxicity occurs, varies between 2 and $5 \mu \mathrm{g} \cdot \mathrm{l}^{-1}$ and is related more to the rate of increase of serum concentration than to the total amount of the drug given. ${ }^{3,4}$ High serum concentrations of bupivacaine have also been reported without any apparent clinical signs of toxicity. ${ }^{5}$ Thus, the serum level at which clinical toxicity occurs is not well established. Serum bupivacaine concentration has previously been determined by gas chromatography; but the advent of column liquid chromatography using solid-phase extraction is a more expedient, convenient and economical method for extracting and analyzing bupivacaine with good accuracy. ${ }^{6}$ Alpha- 1 acid glycoprotein is the most important serum protein binder of bupivacaine, and its concentration is elevated in many clinical situations including post-operative trauma. ${ }^{7}$ Continuous, prolonged infusion of bupivacaine $0.5 \%$ with $1: 200,000$ epinephrine into the extrapleural intercostal space, is a technique used for post-operative pain control after thoracotomy. ${ }^{8}$ To date, no relationship has been found between the post-surgical increase of serum alpha-l acid glycoprotein concentration and the serum bupivacaine concentration with this form of postoperative analgesia. We postulated that the postoperative increase in serum alpha-1 acid glycoprotein concentration might serve as a buffer in binding bupivacaine, thereby preventing any increase in free serum bupivacaine level that might be responsible for clinical manifestation of toxicity.

\section{Methods}

After approval from the Ethics committee and informed consent, nine patients from 32 to $75 \mathrm{yr}$ of age (median $66 \mathrm{yr}$ ), six male and three female, ASA I to III, with carcinoma of the lung, scheduled for elective thoracotomy and lobectomy, were prospectively studied in a controlled fashion. None had been receiving antiarrhythmic drugs.

All patients received a balanced general anaesthetic with thiopentone, pancuronium, alfentanil up to 20 $\mu \mathrm{g} \cdot \mathrm{kg}^{-1}$ for induction. One lung ventilation was established with a single lumen endotracheal tube. A Fogarty catheter was used as an endobronchial blocker. Anaesthesia maintenance was with oxygen, nitrous oxide, and isoflurane. Neostigmine and atropine were used for reversal of muscle relaxants. At the end of the surgical procedure, and before the closure of the chest cavity, an extrapleural costovertebral pouch, $2.5 \mathrm{~cm}$ cephalad and caudad of the incision line, was created by peeling the parietal pleura from the chest wall. Using a \#17 Tuohy needle for separate entry into the chest cavity, an epidural catheter was placed in the pouch and secured by oversewing the parietal pleura. A bolus of $0.3 \mathrm{ml} \cdot \mathrm{kg}^{-1}$ bupivacaine $0.5 \%$ with $1: 200,000$ epinephrine was injected, and this was followed by a continuous infusion of bupivacaine $0.5 \%$ with epinephrine at 0.1 $\mathrm{ml} \cdot \mathrm{kg}^{-1} \cdot \mathrm{hr}^{-1}$ for five consecurive days. This bupivacaine infusion regimen was chosen based on a previous study by Sabanathan $e t a l .{ }^{9}$ Supplemental analgesia with intravenous morphine was available to the patient, given by a nurse as required. Serum concentrations of alpha-1 acid glycoprotein, total and free bupivacaine, and albumin were measured $15 \mathrm{~min}$ after the bolus injection and then every $24 \mathrm{hr}$ for five days. Alpha-l acid glycoprotein serum concentrations were determined by nephelometry on QM 300 protein analyzer (Kallestad, Montréal, PQ) using a Kallestad reagent kit which has an average specificity of $99 \%$ when calculated and measured concentrations were compared. The interassay variability of this test for alpha-1 acid glycoprotein is $2 \%$ $\mathrm{CV}$ in reproducibility. For the determination of free bupivacaine, $0.5 \mathrm{ml}$ serum was filtered through a Centrifree micropartition system (Amicon, Oakville, Ont.) by centrifugation with a fixed angle rotor (200 $\mathrm{X} \mathrm{g}$ ) for $40 \mathrm{~min}$, at ambient temperature. An aliquot of $10 \mu \mathrm{l}$ of the resulting ultrafiltrate was injected into the liquid chromatograph. Due to cost, the free serum bupivacaine was determined in five of nine patients. The chromatographic conditions were the same for the determination of total serum bupivacaine which was performed in nine patients. The procedure for the determination of total and free bupivacaine concentration was validated for accuracy and precision through duplicate analysis and comparison with nominal concentrations of bupivacaine added to drug free serum as described by $\mathrm{R}$. Gupta $e t$ al. The accuracy of the method is 94 to $97 \%$ with a within batch precision of $1.6 \%$ and a between batch precision of $5.1 \%$ for bupivacaine. ${ }^{6}$ Serum albumin was measured by bromocresol green dye binding procedure with a precision of $2.6 \%$, on Hitachi 717 Autoanalyzer (Montréal, PQ).

The significance of differences between means was evaluated using repeated measures analysis of variance. A $P$ value of $<0.05$ was considered significant. Data are presented as means $\pm \mathrm{SD}$.

\section{Results}

There was a steady increase in serum alpha- 1 acid glycoprotein concentration $(P<0.05)$ in post-thoracotomy patients, accompanied by a steady accumulation in total serum bupivacaine concentration $(P<0.05)$, 


\section{SERUM ALPHA-1 ACID GLYCOPROTEIN CONCENTRATION}

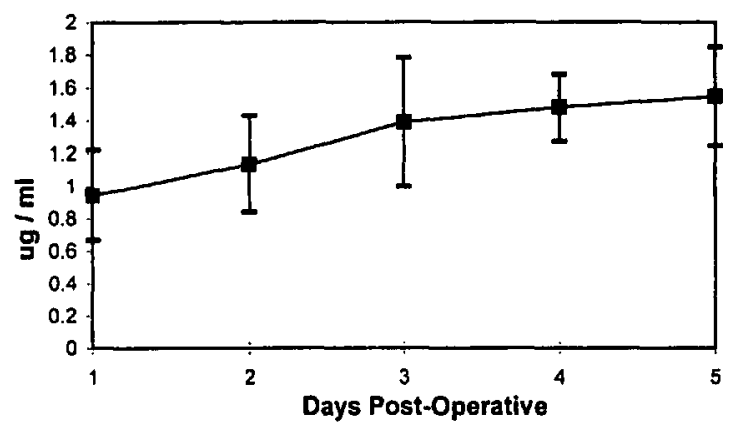

FIGURE 1 Serum alpha-a acid glycoprotein concentrations in nine patientss after thoracotomy.

Mean \pm SD. $P<0.05$.

TOTAL SERUM BUPIVACAINE

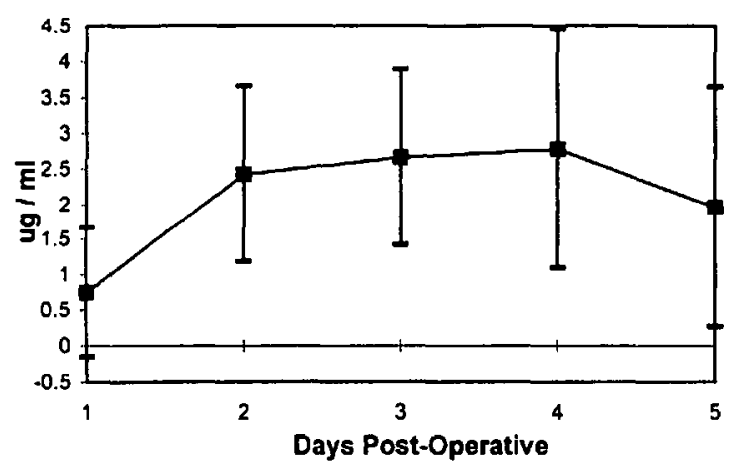

FIGURE 2 Increase in total serum bupivacaine concentration during continuous extrapleural infusion.

Mcan $\pm S D, P<0.05$

(Figures 1,2$)$. No increase in free serum bupivacaine concentrations was observed $(P=0.92)$ (Figure 3$)$. Serum albumin concentration did not change in the first five post-operative days ( $P=0.99$ ) (Figure 4). All patients were monitored in a surgical step down unit for the first $24 \mathrm{hr}$ after surgery and on the surgical ward thereafter. No signs of cardiac arrhythmias or changes in mental status were observed.

\section{Discussion}

Our data have demonstrated that bupivacaine, when given by continuous infusion via the extrapleural space, produces systemic accumulation and a continuous rise in the total serum bupivacaine but without clinical signs of toxicity. The increase observed in the serum concentration of bupivacaine was maximum on Day 4 . There was no change in free serum bupivacaine concentration. In some patients, the increase in total
FREE SERUM BUPIVACAINE LEVEL

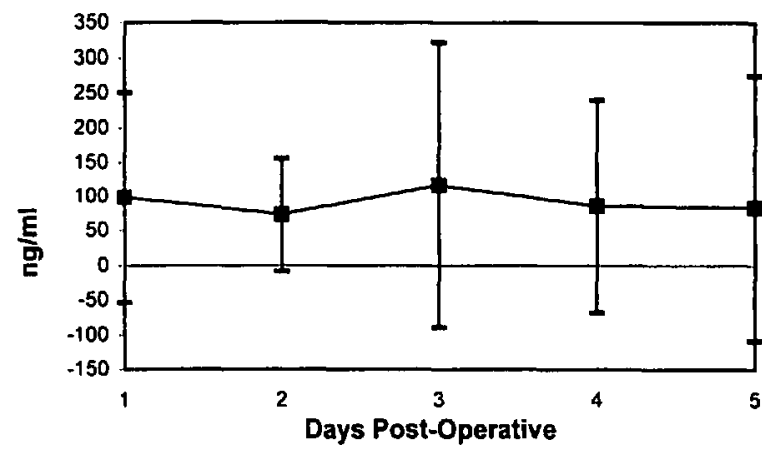

FIGURE 3 Free serum bupivacaine concentrations.

Mean $\pm S D, P=0.92$.

SERUM ALBUMIN

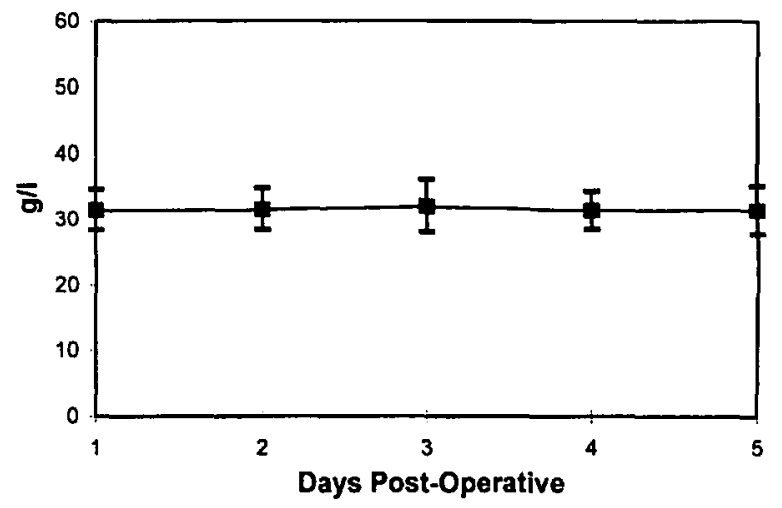

FIGURE 4 Serum albumen concentrations

Mean $\pm S D, P=0.99$.

bupivacaine serum concentration exceeded the $5 \mu \mathrm{g} \cdot \mathrm{ml}^{-1}$ threshold known to cause central nervous system toxicity in man. Nevertheless, no signs of clinical toxicity were observed.

Among the factors that are important in the toxicity of a drug are its bioavailability and its solubility. Tissue binding retains $80 \%$ to $90 \%$ of systemic bupivacaine therefore making it less available. As a lipid soluble local anaesthetic, bupivacaine has an absorption that is not rate limited but is directly proportional to the local blood flow and inversely proportional to the degree of local and systemic tissue binding and its blood drug concentration. ${ }^{10}$ Previous reports of the threshold for serum bupivacaine toxicity were determined after intravenous injection of the drug, therefore bypassing the influence of drug absorption. The resulting plasma concentrations would not be comparable with those after injection of the drug at other 
sites or following different modes of administration. Therefore, the toxic serum concentration of bupivacaine, when this drug is administered extravascularly and by continuous infusion that result in a continuous increase in serum concentration, is not known.

Alpha- 1 acid glycoprotein, at normal $\mathrm{pH}$ conditions, plays a major role in the binding of bupivacaine at serum concentrations of $<5 \mu \mathrm{g} \cdot \mathrm{ml}^{-1}$ and has a high affinity and low capacity for bupivacaine. "In this study, a steady increase in alpha- 1 acid glycoprotein was observed during the post-operative period between day 1 and day $5(P<0.05)$. Bupivacaine at low concentrations would preferentially bind to alpha-l acid glycoprotein. Its absorption, when given extrapleurally, coupled with the increased availability of alpha-l acid glycoprotein in the post-operative period would explain the continuous rise in total serum bupivacaine concentration and the maintenance of free serum bupivacaine at a constant concentration observed during our study.

Albumin is another important serum binding protein with a low affinity and high capacity for bupivacaine at concentrations of $>20 \mu \mathrm{g} \cdot \mathrm{ml}^{-1}$, and this does not vary with $\mathrm{pH}$. In this study there were no changes in serum albumin concentration between Day 1 and Day $5(P=0.99)$. Serum bupivacaine concentrations were insufficient for albumin binding of bupivacaine.

In conclusion, this study showed that, during continuous extrapleural infusion of bupivacaine over five days, there was a progressive increase in the total serum bupivacaine concentration. This increase, although approaching previously suggested "toxic levels" in some patients, was not associated with any clinical signs of toxicity. The serum level of alpha-1 acid glycoprotein is also increased in post-thoracotomy period. This increase in serum alpha- 1 acid glycoprotein may facilitate bupivacaine binding, and thus augments its postoperative total serum concentration. Free serum bupivacaine concentration did not show any increase. It is therefore suggested that during the postoperative period, the assessment of serum bupivacaine toxicity, when this drug is administered extravascularly and in continuous infusion, might be better determined by the measurement of free serum bupivacaine concentration.

\section{Acknowledgement}

The authors thank Drs. M. Levine, F. Baxter for reviewing the manuscript.

\section{References}

1 Shnider SM, Levinson G. Anesthesia for Obstetrics, 2nd ed. 1987.

2 Albright $G A$. Cardiac arrest following regional anesthesia with etidocaine or bupivacaine. Anesthesiology $1979 ; 51: 285-7$.
3 Tucker GT, Mather LE. Clinical pharmacokinetics of local anaesthetics. Clin Pharmacokinet 1979; 4: 241-78.

4 Scott $D B$. Evaluation of the toxicity of local anaesthetic agents in man. Br J Anaesth 1975; 47: 56-61.

5 Ross RA, Clarke JE, Armitage EN. Postoperative pain prevention by continuous epidural infusion. Anaesthesia $1980 ; 35: 663-8$.

6 Gupta RN, Dauphin A. Column liquid chromatographic determination of bupivacaine in human serum using solid-phase extraction. J Chromatogr B Biomed Appl 1994; 658: 113-9.

7 Edwards DJ, Lalka D, Cerra F, Slaughter RL. Alpha,acid glycoprotein concentration and protein binding in trauma. Clin Phamacol Ther 1982; 31: 62-7.

8 Richardson J, Sabanathan S, Eng J, et al. Continuous intercostal nerve block versus epidural morphine for postthoracotomy analgesia. Ann Thorac Surg 1993; 55: 377-80.

9 Sabanathan S, Mearns AJ, Bickford Smith PJ, et al. Efficacy of continuous extrapleural intercostal nerve block on post-thoracotomy pain and pulmonary mechanics. Br J Surg 1990; 77: 221-5.

10 Tucker GT. Pharmacokinetics of local anaesthetics. Br J Anaesth 1986; 58: 717-31.

11 Denson D, Coyle D, Thompson G, Myers J. Alpha ${ }_{1}$-acid glycoprotein and albumin in human serum bupivacaine binding. Clin Pharmacol Ther 1984; 35: 409-15.

12 Mazoit JX, Denson DD, Samii K. Pharmacokinetics of bupivacaine following caudal anesthesia in infants. Anesthesiology 1988; 68: 387-91.

13 Piblajamäki KK, Lindberg RLP. Bupivacaine with and without adrenaline in interscalene brachial plexus blockade. Br J Anaesth 1987; 59: 1420-4.

14 Seeling $W$, Altemeyer $K-H$, Berg S, Dick W, Kossmann $B$. Serum bupivacaine concentrations in patients with continuous peridural anesthesia administered by thoracic catheter. (German) Anaesthesist 1982; 31: 434-8.

15 Veering BTh, Burm AGL, Gladines MPRR, Spierdijk $J o h$. Age does not influence the serum protein binding of bupivacaine. Br J Clin Parmacol 1991; 32: 501-3.

16 Hartrick CT, Dirkes WE, Coyle DE, Raj PP, Denson $D D$. Influence of bupivacaine on mepivacaine protein binding. Clin Pharmacol Ther 1984; 36: 546-50.

17 Renck H, Edström H, Kinnberger B, Brandt G. Thoracic epidural analgesia - II: Prolongation in the early postoperative period by continuous injection of 1.0\% bupivacaine. Acta Anaesthsiol Scand 1976; 20: 47-56. 